\title{
SWEDISH LAWS REGULATING THE SALE OF POISONS.
}

By C. Hersch, F.C.S., F.I.C.

Read before the Society of Public Analysts, on March 16th, 1881.

Having had occasion to examine into the laws affecting the sale of poisons in different countries, I thought it might be of interest to the Society to learn the principal regulations 
in force in Sweden (where much pains has been taken in the matter by the Board of Health) without wading through three very verbose Decrees in a language not generally " understanded of the people," but which I am fortunate enough to be able to get translated to any extent.

The 1st Decree bears date January 6th, 1876, and concerns "the Sale of Arsenic and other poisonous mutters."

All through arsenic holds a very prominent place, many of the restrictions applying to it alone. Why this should be it is somewhat difficult to understand.

\section{Clause I.}

Enacts that white arsenic, or arsenic acid, shall not be made within the Kingdom without the King's permission, and shall only be imported by a pharmaceutical chemist, or by licensed manufacturers, who require this poisonous ingredient.

Clause II.

Section 1 enacts that a pharmaceutist wishing to import arsenic must give notice to the Board of Health, and a manufacturer to the Board of Trade, and obtain a certificate addressed to the Custom House at which the arsenic is to be received, slating where it is to be stored and what quantity the applicant may import, such certificate to be null and void after three moriths.

Section 2.-Custom House to keep proper record of every importation, and report to Boards of Health and Trade every year.

Clause III.

Only principals or qualified managers of druggists' shops to be allowed to sell arsenic. Clause IV.

Arsenic not to be sold by phurmaceutist himself, except as follows :-

(a) On a recently issued prescription of a qualified medical man, dentist, or veterinary surgeon. Buyer to give receipt to seller stating what he has bought.

(b) Qualified manager may act in absence of principal.

(c) On a written requisition to a particular druggist, stating quantity and purpose for which required, duly signed. Or arsenic may be delivered to a known scientific chemist, or to a manufacturer who requires it in his business; but either must produce a warrant from a magistrate or a Crown bailiff, not more than a year and a day old. Buyer to sign an undertaking to use all proper precautions in storing the poisons, and not to part with any to anyone. Druggist may refuse to supply if he thinks fit.

Section 2.-Arsenic shall not be sold for destroying rats or vermin or for embalming.

\section{Clause V.}

All arsenical preparations delivered according to prescriptions to be officially sealed by the druggist. In all other cases to be in strong glass vessels with proper stoppers, or in strong and securely fastened wooden vessels, sealed by the druggist, and labelled with name of druggist, time of delivery, name of preparation, and the word poison.

Clause VI.

Druggists keeping arsenic to undertake to keep it in such vessels as in V., and under lock and key; no one to have access thereto except druggist himself or his sworn agent.

Clause VII.

Arsenic only to be transported in similar cases, labelled with names of consignor and consignee, quantity, \&c. 
Clause VIII.

Druggist to keep arsenic book, paged : to be submitted to a magistrate and signed by him before any entry is made, and he (the magistrate) shall state number of pages at date of delivery. Arsenic book to be delivered to magistrate when full, and by him kept 10 years.

\section{Clause IX.}

All prescriptions and orders on which arsenic has been sold to be attached to arsenic book and kept with it.

\section{Clause X.}

Authorized professional men to inspect arsenic book periodically and report to Board of Trade. Magistrate of county to inspect all stocks of arsenic at least once a year, and compare with books and report result of inspection.

Clause XI.

All persons wishing to manufacture any poisonous article must hold a certificate from one of the Universities, the Medico-Chirurgical Institute, or the Technical School.

\section{Clause XII.}

Poisonous articles, other than arsenic, only to be sold by-(a) Principals of Drug Stores; (b) Pharmacentical Chemists. All rules for sale of arsenic to apply to other poisons. All scales, weights, scoops, \&c., used in weighing or measuring any poison, to be kept for that purpose alone. Poisons to be kept in a separate room to which no one but principal or sworn manager has access.

\section{Cluause XVII.}

Strychnine or any preparation thereof only to be allowed for killing vermin, under special permit, to be granted by Crown Inspector, if he deem the circumstances to warrant it. Such permit to state all particulars and length of time it may remain in force.

\section{Clause XVIII.}

Children's toys not to be painted with poisonous water colours. Colour boxes not to be sold containing poisonous colours unless provided with prominent label stating the fact.

Clause XIX.

No poisonous colours to be used in eatables of any kind. Board of Health to publish list of colours that may be used for this purpose. No leaden moulds or papers prepared with lead to be used by pastrycooks for preparing or wrapping their goods.

\section{Clause XX.}

Paper hangings, roller blinds, textile fabrics, artificial flowers, or other goods in water colour, not to contain arsenic. Lamp shades, wafers, stearine or other candles, not to contain arsenic or other poisonous matter.

\section{Penalties.}

For importing arsenic otherwise than as directed, 200 to 1000 crowns, and forfeiture of goods.

For manufacturing poisonous wares without a license, 100 to 500 crowns.

Any manufacturer having a license infringing any one of the rules, 50 to 500 crowns.

Selling without a license, 100 to 500 crowns.

Infringement of rules for selling, 50 to 500 crowns.

If infringement be made by an apothecary's sworn assistant, master not to be liable.

All other infringement of rules, 25 to 100 crowns. 
All Customs' servants, railway officials, \&c., to watch over import or transport of poisonous matters, and report same to authorities, or Customs' servants may seize such goods.

Commissioners of Public Iealth to watch for infringements, and if they see any carelessness in keeping or selling poisons by licensed persons, are to admonish, and, on second offence, report to police.

Any poisons seized to be sealed and kept till it is decided in a court of law what is to be done with them. Notice of seizure to be given to Chief of Police.

Any person being in legal possession of arsenic and wishing to get rid of the responsibility may hand it over to the nearest apothecary, who shall take charge of it as if it were his own, provided the weight does not exceed ten pounds: if above this weight it must be handed to Crown bailiff.

One copy of this Decree, and also of the Proclamation, to be issued by Board of Health, to be accessible at every apothecary's and manufacturer's, or the house of anyone licensed to sell or keep poisons, under penalty of 10 to 50 crowns. Fines to be divided as follows:-One-third to the Crown, two-thirds to Public Prosecutor. If information be given by a private individual then he and Public Prosecutor divide this two-thirds between them.

To take effect after July 1st, 1876.

$$
\text { (To be continued.) }
$$

